\title{
Influence of spontaneous fermentation leavens from cereal flour on the indicators of the technological process of making wheat bread
}

\author{
Inna Hetman, Larysa Mykhonik, \\ Oleg Kuzmin, Anastasiia Shevchenko
}

National University of Food Technologies, Kyiv, Ukraine

\section{Keywords: \\ Fermentation \\ Leaven \\ Dough \\ Bread}

\section{Article history: \\ Received \\ 19.03.2021 \\ Received in \\ revised form \\ 01.06 .2021 \\ Accepted \\ 30.09.2021}

\section{Corresponding author:}

Larysa

Mykhonik

E-mail:

gm_lora@i.ua

DOI:

$10.24263 / 2304-$

974X-2021-103-6

\section{Abstract}

Introduction. The aim of the research was to determine the carbohydrate-amylase complex of oatmeal and green buckwheat flour, the process of preparation of spontaneous fermentation leavens using of these types of flour, to establish the influence of spontaneous fermentation leavens on technological indicators and wheat bread quality.

Materials and methods. Oatmeal flour, green buckwheat flour, spontaneous fermentation leavens prepared using these types of flour, and wheat bread with the addition of these leavens were studied. Accelerated and express method of drying, iodometric, volumetric, autolytic test, titration and $\mathrm{pH}$-metry methods, method of restoring the color of the indicator, method of displaced volume by the grain were used.

Results and discussion. Wheat flour of the first grade was the control sample in the research. The sugar-forming ability of oat and buckwheat flour was lower than in the control sample by $19.4 \%$ and $56.4 \%$; autolytic activity by $36.9 \%$ and $43.1 \%$; total gas formation by $31.1 \%$ and $38.6 \%$, respectively. The decrease in enzymatic activity was due to differences in chemical composition and technology of preparation of cereals used to produce oatmeal and buckwheat flour.

In mixtures of wheat flour with oat or buckwheat flour, the sugarforming ability was higher than in the control sample by $15.1 \%$ and $10.4 \%$; gas-forming capacity by $12.7 \%$ and $7.3 \%$, respectively. This was due to the effect of the active $\beta$-amylase of wheat flour on the smaller starch grains of cereal flour.

It was established that after the fifth renewal of leaven from oat and buckwheat flour it could be used for bread making, as the quality of buckwheat and oat leavens was stabilized due to physicochemical parameters (acidity - 16.0-18.0 degrees, lactic acid bacteria activity 45-60 min).

The addition of the studied leavens in the amount up to $12 \%$ by weight of flour in the dough allowed obtaining products with organoleptic and physicochemical parameters close to the control sample.

Conclusions. Technological properties of oatmeal and green buckwheat flour allowed using them as a nutrient medium for spontaneous fermentation leavens in order to intensify technological processes and improve the nutritional value of wheat bread. 


\section{- Food Technology -}

\section{Introduction}

It is necessary to expand the range and increase the nutritional value of wheat bread as it is unbalanced in terms of basic nutrients. The impetus for improving technology is also to increase public awareness of health and nutrition as a factor, which ensures the body's resistance to the negative effects of the environment and emotional stress (Ivanov et al., 2021; Kaprelyants et al., 2019; Sharma et al., 2020).

It is advisable to replace wheat flour with non-traditional types, in particular, cereal flour, which has higher nutritional value (Coelho and de Salas-Mellado, 2015; Drobot et al., 2014). Most types of cereal flour should be used in a mixture with wheat flour, because the underdeveloped proteinproteinase complex causes the inability to form gluten when kneading the dough. Other technological indicators of flour (in particular, carbohydrate-amylase complex), which directly affect the course of physicochemical, biochemical, microbiological processes in semi-finished products (leaven, dough) and the quality of finished products also requires studies (Flander et al., 2007; Hadnađev et al., 2011).

The purpose of research was the establishment of carbohydrate-amylase complex of oatmeal and green buckwheat flour, study of the process of preparation of spontaneous fermentation leaven based on these types of flour, study of the influence of spontaneous fermentation leaven on the technological process and quality indicators of wheat bread.

The main objectives of the research:

- Determination of the carbohydrate-amylase complex of cereal flour, namely oatmeal and green buckwheat flour, and mixtures of these types of flour with wheat flour;

- Development of schemes for dilution of spontaneous fermentation leavens based on green buckwheat flour and oatmeal;

- Carrying out of trial laboratory baking of wheat bread with the investigated leavens with the aim of proving efficiency of their use.

\section{Literature analysis}

Oatmeal and green buckwheat flour are promising products for processing in baking.

Oatmeal contains about $10 \%$ protein, up to $6.5 \%$ fat with a small amount of sugar (up to $1 \%$ ) and starch (about 65\%). The flour contains vitamins B1, B2, B6, B9, E, PP, trace elements (iron, chromium, and zinc), macroelements (potassium, magnesium, phosphorus, and sodium), and dietary fiber. Oatmeal protein is better balanced in amino acid composition than wheat protein (Berski et al., 2011; Flander, et al., 2007).

Features of its carbohydrate composition are the presence of soluble polysaccharides: pentosans (up to $14.0 \%$ ), levulezan (up to $2.0 \%$ ), as well as immunostimulants and prebiotics $\beta$ glucan (Keying et al., 2009; Rasane et al., 2015).

Absence of heat treatment operation in the production of green buckwheat flour allows to preserve the full range of vitamins, macro- and micronutrients, enzyme complex and powerful antioxidant properties (Dziadeka et al., 2016).

The protein contents in green buckwheat flour vary from 13 to $15 \%$. This protein is well digested and is rich in valuable amino acids. Carbohydrate contents are $62-68 \%$ with a glycemic index of about 15, which gives the flour dietary properties. Fiber contents in buckwheat flour are about $6-12 \%$. Fiber promotes the excretion of toxins from the body and improves the functioning of the gastrointestinal tract (Bonafaccia et al., 2003; Sakač et al., 2011).

Green buckwheat flour is rich in B vitamins (B1, B2, B6, B9), E, PP, macronutrients potassium, magnesium, phosphorus; trace elements - iron, copper, zinc, chromium, molybdenum, manganese (Bondarenko et al., 2019). 
The main functions of the use of leavens in wheat bread technology are antimicrobial, ie, ensuring microbiological purity in case of Escherichia coli, especially in summer, accelerating ripening and improving the rheological characteristics of the dough (Lebedenko et al., 2013).

Biological leavens of spontaneous fermentation have a number of advantages:

- Simplification of the leaven production process;

- Saving of yeast and pure cultures of lactic acid bacteria (LAB);

- Saving production space;

- Prompt response to market needs, increase or decrease in volume and range (Banu et al., 2010; Sylchuk et al., 2017; De Vuyst et al., 2005).

Information on the technologies of spontaneous fermentation leavens differs, in addition, there is a lack of research and clear schemes for the production of leavens in case of discrete production.

Most research concerns the technology of rye-wheat bread on rye leaven (Sylchuk et al., 2017), and cases when non-traditional types of flour such as buckwheat, oat and corn replace part of the rye flour (Pshenychnyuk et al., 2013; Chelyabiyeva and Sosedova, 2018). The influence of hop extract on microbiological stability of spontaneous wheat leavens and finished products with the addition of these leavens was investigated; the efficiency of using hop spontaneous leavens in wheat bread technology was proved (Yurchak et al., 2009).

However, there is no comparative characteristic of leavens using only cereal flour as a nutrient medium, without a mixture with traditional rye or wheat flour.

A large-scale study of the microflora of spontaneous fermentation leavenss from wheat and barley flour was carried out. Studies confirmed the need to control the temperature of the environment during the cultivation of leavens to ensure the stability of their microbiological state (De Vuyst, Neysens 2005; Harth et al., 2016).

Leavens from barley flour of spontaneous fermentation and with pure cultures of microorganisms were derived. It was established that at the end of fermentation the amount of soluble dietary fiber, namely $\beta$-glucan, in the leaven decreases, which proves its prebiotic properties (Andersson et al., 2004).

Insufficient attention is paid to the differences in the cycles of preparing leavens using wheat flour, both traditional and barley, as well as the influence of parameters (humidity, temperature) on the physicochemical quality of finished leavens.

Studies of the influence of spontaneous fermentation rice leaven on the rheological properties of the dough, indicators of the technological process of bread from rice flour showed that the processes of dough maturation accelerated and the intensity of acid accumulation increased (Demirkesen Mert et al., 2014; Coda et al., 2014).

Scientists have a leaven of spontaneous fermentation from corn flour was developed and the spontaneous microflora at different $\mathrm{pH}$ values was studied. The optimal $\mathrm{pH}$ value was 3.65-3.90 units of device at which strains of lactic acid bacteria and yeast of high activity and lifting power were detected (Zannini et al., 2009). Important indicators of quality for leavens are also the titrated acidity and humidity, which are insufficiently studied when using non-traditional nutrient media.

Leavens of spontaneous fermentation from buckwheat flour in different fermentation conditions were studied, species of lactic acid bacteria and yeast, more traditional for wheat and rye yeast were identified, and some species, including Pediococcus pentosaceus, Leuconostoc holzapfelii, Lactobacalliscus Lactobacillus, Lactobacillus graminis and Weissella cibaria, Lactobacillus plantarum were unconventional (Moroni et al., 2011; Moroni et al., 2012). The influence of leaven on the technological process and the quality of bread products remains unexplored.

The analysis of the above articles allowed concluding that the detailed study and description require features of the cultivation cycles and production cycle for each type of flour with specific parameters. It is also important to study the influence of the obtained leavens on the technological process and the quality of finished products. 


\section{Materials and methods}

\section{Materials}

\section{Preparation of cereal flour leavens}

Leaven preparation consists of the breeding cycle and production cycle. To prepare the leaven, flour was mixed with water in the ratio specified in Table 1, 2.

Table 1

Sequence of derivation of spontaneous fermentation leavens from green buckwheat flour in the breeding cycle

\begin{tabular}{|c|c|}
\hline Stage & $\begin{array}{c}\text { Characteristics, biotechnological } \\
\text { indicators }\end{array}$ \\
\hline $\begin{array}{l}\text { 1. Mixing: } \\
\text { Flour, } \mathrm{kg}-0.05 \\
\text { Water, } \mathrm{kg}-0.075\end{array}$ & $\begin{array}{l}\text { In } 24 \text { hours of fermentation on stage } 1 \text { : } \\
\text { Acidity, degrees }-3.2\end{array}$ \\
\hline $\begin{array}{l}\text { 2. In } 24 \text { hours after mixing (first renewal): } \\
\text { Flour, } \mathrm{kg}-0.05 \\
\text { Water, } \mathrm{kg}-0.075 \\
\text { Pre-prepared leaven (PPL), } \mathrm{kg}-0.125\end{array}$ & $\begin{array}{l}\text { In } 24 \text { hours of fermentation on stage } 2 \text { : } \\
\text { Acidity, degrees }-6.4 \\
\text { Volume increase coefficient }-1.1 \\
\text { Activity of LAB, min - low ( } 115 \mathrm{~min}) \text {; } \\
\text { Beginning of fermentation. }\end{array}$ \\
\hline $\begin{array}{l}\text { 3. In } 48 \text { hours after mixing (second } \\
\text { renewal): } \\
\text { Flour, } \mathrm{kg}-0.1 \\
\text { Water, } \mathrm{kg}-0.15 \\
\text { PPL, } \mathrm{kg}-0.25\end{array}$ & $\begin{array}{l}\text { In } 24 \text { hours of fermentation on stage } 3 \text { : } \\
\text { Acidity, degrees }-10.4 \\
\text { Volume increase coefficient }-1.21 \\
\text { Activity of LAB, min - low ( } 92 \mathrm{~min}) \text {; } \\
\text { Moderate fermentation. }\end{array}$ \\
\hline $\begin{array}{l}\text { 4. In } 72 \text { hours after mixing (third } \\
\text { renewal): } \\
\text { Flour, } \mathrm{kg}-0.2 \\
\text { Water, } \mathrm{kg}-0.3 \\
\text { PPL, } \mathrm{kg}-0.5\end{array}$ & $\begin{array}{l}\text { In } 24 \text { hours of fermentation on stage } 4 \text { : } \\
\text { Acidity, degrees }-14.6 \\
\text { Volume increase coefficient }-1.3 \\
\text { Activity of LAB, min - high ( } 74 \mathrm{~min}) \text {; } \\
\text { Intensive fermentation. }\end{array}$ \\
\hline $\begin{array}{l}\text { 5. In } 96 \text { hours after mixing (fourth } \\
\text { renewal): } \\
\text { Flour, } \mathrm{kg}-0.4 \\
\text { Water, } \mathrm{kg}-0.6 \\
\text { PPL, } \mathrm{kg}-1.0\end{array}$ & $\begin{array}{l}\text { In } 24 \text { hours of fermentation on stage } 5 \text { : } \\
\text { Acidity, degrees }-16.0 \\
\text { Volume increase coefficient }-1.35 \\
\text { Activity of LAB, min - high ( } 70 \mathrm{~min}) \text {; } \\
\text { Moderate fermentation. }\end{array}$ \\
\hline $\begin{array}{l}6 . \text { In } 120 \text { hours after mixing (fifth } \\
\text { renewal): } \\
\text { Flour, } \mathrm{kg}-0.8 \\
\text { Water, } \mathrm{kg}-1.2 \\
\text { PPL, } \mathrm{kg}-2.0 \text {. }\end{array}$ & $\begin{array}{l}\text { In } 24 \text { hours of fermentation on stage } 6 \text { : } \\
\text { Acidity, degrees }-16.6 \\
\text { pH, units of device }-3.79 \\
\text { Humidity, } \%-60.5 \\
\text { Volume increase coefficient }-1.3 \\
\text { Activity of LAB, min }- \text { high }(45 \mathrm{~min}) \text {. }\end{array}$ \\
\hline
\end{tabular}


Table 2

Sequence of preparing of spontaneous fermentation leaven from oatmeal flour in the breeding cycle

\begin{tabular}{|c|c|}
\hline Stage & $\begin{array}{l}\text { Characteristics, biotechnological } \\
\text { indicators }\end{array}$ \\
\hline $\begin{array}{l}\text { 1. Mixing: } \\
\text { Flour, } \mathrm{kg}-0.05 \\
\text { Water, } \mathrm{kg}-0.1\end{array}$ & $\begin{array}{l}\text { In } 24 \text { hours of fermentation on stage } 1 \text { : } \\
\text { Acidity, degrees }-3.8\end{array}$ \\
\hline $\begin{array}{l}\text { 2. In } 24 \text { hours after mixing (first renewal): } \\
\text { Flour, } \mathrm{kg}-0.05 \\
\text { Water, } \mathrm{kg}-0.1 \\
\text { PPL, } \mathrm{kg}-0.15\end{array}$ & $\begin{array}{l}\text { In } 24 \text { hours of fermentation on stage } 2 \text { : } \\
\text { Acidity, degrees }-7.8 \\
\text { Volume increase coefficient }-1.4 \\
\text { Activity of LAB, min - low (100 min); } \\
\text { Beginning of fermentation. }\end{array}$ \\
\hline $\begin{array}{l}\text { 3. In } 48 \text { hours after mixing (second } \\
\text { renewal): } \\
\text { Flour, } \mathrm{kg}-0.1 \\
\text { Water, } \mathrm{kg}-0.2 \\
\text { PPL, } \mathrm{kg}-0.3\end{array}$ & $\begin{array}{l}\text { In } 24 \text { hours of fermentation on stage } 3 \text { : } \\
\text { Acidity, degrees }-11.0 \\
\text { Volume increase coefficient }-1.56 \\
\text { Activity of LAB, min - low }(85 \mathrm{~min}) \text {; } \\
\text { Intensive fermentation. }\end{array}$ \\
\hline $\begin{array}{l}\text { 4. In } 72 \text { hours after mixing (third renewal): } \\
\text { Flour, } \mathrm{kg}-0.2 \text {; } \\
\text { Water, } \mathrm{kg}-0.4 \\
\text { PPL, } \mathrm{kg}-0.6\end{array}$ & $\begin{array}{l}\text { In } 24 \text { hours of fermentation on stage } 4 \text { : } \\
\text { Acidity, degrees - } 15.6 \\
\text { Volume increase coefficient }-1.63 \\
\text { Activity of LAB, min - high ( } 68 \mathrm{~min}) \text {; } \\
\text { Intensive fermentation. }\end{array}$ \\
\hline $\begin{array}{l}\text { 5. In } 96 \text { hours after mixing (forth renewal): } \\
\text { Flour, } \mathrm{kg}-0.4 \\
\text { Water, } \mathrm{kg}-0.8 \\
\text { PPL, } \mathrm{kg}-1.2\end{array}$ & $\begin{array}{l}\text { In } 24 \text { hours of fermentation on stage 5: } \\
\text { Acidity, degrees }-17.5 \\
\text { pH, units of device }-3.63 \\
\text { Масова частка вологи, } \%-67.0 \\
\text { Volume increase coefficient }-1.68 \\
\text { Activity of LAB, min - high ( } 48 \mathrm{~min}) \text {. }\end{array}$ \\
\hline
\end{tabular}

The dilution cycle lasted 120 hours at a temperature of $26-28^{\circ} \mathrm{C}$. In this cycle, every 24 hours a nutritious mixture of flour and water (temperature $28-30^{\circ} \mathrm{C}$ ), in a ratio of $1: 1.25$ was added to the previous ripe leaven. Then the leaven can be used in the production cycle for making bread.

The production cycle involves the preparation of leaven with humidity $(60 \pm 5) \%$, in which the selection of leaven occurs every $10-12$ hours. $70 \%$ of leaven is selected for the production, and a nutritious mixture of flour and water (ratio 1:1.25) is added to the remaining mass. The acidity of the leaven is 16.0-18.0 degrees, $\mathrm{pH}=3.85-3.70$ units of device, the activity of lactic acid bacteria - 55-65 $\mathrm{min}$.

The dilution cycle lasted 96 hours at a temperature of $26-28{ }^{\circ} \mathrm{C}$ every 24 hours a nutritious mixture of flour and water (temperature $28-30^{\circ} \mathrm{C}$ ), in a ratio of 1:1.2 was added to the previous ripe leaven. Then the leaven can be used in the production cycle for making bread.

The production cycle involves the preparation of leaven with humidity $(65 \pm 5) \%$, in which the selection of leaven occurs every 10-12 hours. $70 \%$ of leaven is selected for the production, and a nutritious mixture of flour and water (ratio 1:2). The acidity of the leaven is 16.0-18.0 degrees, $\mathrm{pH}=3.86-3.72$ units of device, the activity of lactic acid bacteria -45 60 minutes 


\section{- Food Technology -}

\section{Preparation of wheat bread using leavens}

Laboratory baking of wheat bread with addition of $12 \%$ of leaven to the weight of flour was carried out. Sample with the addition of wheat leaven of spontaneous fermentation was a control sample. $6-8 \%$ of cereal flour is added with leaven, wheat flour was replaced with the appropriate amount of cereal flour. The dough was kneaded according to the recipe for 5-7 minutes using a kneading machine. Yeast suspension and saline solution were preprepared. The amount of water was calculated by subtracting water for kneading dough from the total amount. Water temperature was $(37 \pm 2){ }^{\circ} \mathrm{C}$. After kneading, dough was left for fermentation for $90-100 \mathrm{~min}$ in proofer at a temperature of $30-32{ }^{\circ} \mathrm{C}$ and a relative humidity not less than $80 \%$. After that, the dough was divided into dough pieces of $270-280 \mathrm{~g}$, molded, put to forms and left in proofer for keeping at a temperature of $33-35{ }^{\circ} \mathrm{C}$ and a relative humidity not less than $80 \%$ for 30-35 minutes. The kept dough pieces were baked in a steamhumidified oven at a temperature of $180-190{ }^{\circ} \mathrm{C}$ for $25-30$ minutes.

\section{Methods}

\section{Mass fraction of sugars}

The mass fraction of sugars was determined by the iodometric method with preliminary hydrolysis of the prepared aqueous extract (Manual of Methods of Analysis of Food, Beverages, Sugar and Confectionery Product, 2012).

\section{Sugar-forming ability}

The indicator of sugar-forming ability is the amount of mg of maltose formed in a waterflour suspension from $10 \mathrm{~g}$ of flour and $50 \mathrm{~cm}^{3}$ of water in a volumetric flask per $100 \mathrm{~cm}^{3}$ for $1 \mathrm{~h}$ of fermentation at a temperature of $27^{\circ} \mathrm{C}$ (after pre-precipitation of proteins). In parallel, control with $50 \mathrm{~cm}^{3}$ of distilled water is conducted.

The amount of maltose is determined in the transparent filtrate by iodometric method (Manual of Methods of Analysis of Food, Beverages, Sugar and Confectionery Product, 2012).

\section{Autolytic activity}

Autolytic activity is determined by the method of autolytic test by the accumulation of water-soluble substances in the water-flour suspension when heated in a boiling water bath.

A porcelain cup (weighing 30-40 g, $50 \mathrm{~cm}^{3}, 7 \mathrm{~cm}$ high) is weighed together with a glass rod, which remains in it until the end of the determination. A portion of flour $1 \pm 0.05 \mathrm{~g}$ is weighed into a glass. $10 \pm 0.02 \mathrm{~cm}^{3}$ of distilled water is poured there and mixed.

Filled glasses are simultaneously immersed in a boiling water bath with uniform boiling of water in it. The bath should have the following parameters: capacity $1.5-1.8 \mathrm{dm}^{3}$, diameter - about $18 \mathrm{~cm}$, height $-9-10 \mathrm{~cm}$. The bath is covered with a lid with six holes according to the size of the glasses. All six glasses are immersed in the bath to provide the water level in it $-0.75-1.0 \mathrm{~cm}$ lower than the water level in the bath. The distance from the bottom of glasses to the bottom of the bath should be $2-3 \mathrm{~cm}$.

If less than three determinations are performed at the same time, the bath should still be filled in such way to pour $10 \mathrm{~cm}^{3}$ of distilled water in each of six glasses. 
The heating of the samples is continued for 15 minutes, and during the first 2-3 minutes the contents of the beakers are stirred several times with a stick for uniform gelatinization. After its completion, each glass is covered with a funnel to prevent excessive evaporation. After 15 minutes of heating, the beakers are simultaneously removed and $20 \pm 0.02 \mathrm{~cm}^{3}$ of distilled water is poured into them, stirred vigorously and cooled to room temperature. The total weight of the autolysate is adjusted on the scales to $30 \pm 0.05 \mathrm{~g}$ with an accuracy of 0.01 (adding $0.2-0.5 \mathrm{~cm}^{3}$ of water). Then the mixture is stirred until foaming and filtered through a filter. It is advisable to leave the precipitate, which is poorly filtered, in a glass, and pour a layer of liquid on the filter.

During filtration, the first portions are discarded, and the following are applied to the prism of a precision refractometer. Using the table attached to the device, the content of dry matter $(\mathrm{DM})$ in the filtrate is found and this value is multiplied by 30 , taking into account the dilution.

The content of water-soluble substances in terms of DM of flour, is calculated by the formula:

$$
\mathrm{x}=\frac{\mathrm{a} \times 100}{100-W_{f}}
$$

where $\mathrm{W}_{\mathrm{f}}$ is humidity of flour, \%; $\mathrm{a}$ is the content of water-soluble substances in flour, $\%$. The discrepancy between two parallel definitions should not exceed $3 \%$.

\section{Gas-forming ability}

The indicator of gas-forming ability is considered to be the amount of $\mathrm{cm}^{3}$ of carbon dioxide $\left(\mathrm{CO}_{2}\right)$ released during 5 hours of fermentation of the dough from $100 \mathrm{~g}$ of flour, $60 \mathrm{ml}$ of water and $10 \mathrm{~g}$ of yeast at a temperature of $30^{\circ} \mathrm{C}$.

This indicator was determined by volumetric method by $\mathrm{CO}_{2}$ volume emitted under constant temperature and pressure (Munteanu et al., 2019; Verheyen et al., 2015).

\section{Titrated and active (pH) acidity}

Titrated acidity was determined in semi-finished products (leaven, dough) and finished products (Manual of Methods of Analysis of Food, Beverages, Sugar and Confectionery Product, 2012).

Measurement of the concentration of hydrogen ions (hydrogen index) in the leaven is measured by electrometric method using a laboratory $\mathrm{pH}$ meter. The $\mathrm{pH}$ value is determined by immersing the appropriate electrodes in a beaker with a prepared sample of leaven. Indicators ( $\mathrm{pH}$ and temperature) are taken directly from the scale of the device.

\section{Activity of lactic acid bacteria (LAB)}

LAB activity is calculated by the intensity of recovery of the blue color of methylene blue. $20 \mathrm{~g}$ of leaven is mixed with $40 \mathrm{~cm}^{3}$ of water heated to a temperature of $40{ }^{\circ} \mathrm{C} .10 \mathrm{~cm}^{3}$ is taken from the mixture in two tubes. $1 \mathrm{~cm}^{3}$ of $0.05 \%$ aqueous solution of methylene blue is added to one tube. The second test tube is a control tube. The tubes are placed in a thermostat at a temperature of $40^{\circ} \mathrm{C}$. LAB activity is determined by the time required to decolorize the sample.

\section{Humidity by the accelerated method}

Determination of humidity was carried out in flour and finished products, drying is carried out by air-heat method, by dehydration of flour in an air-heat cabinet with fixed parameters of temperature and duration of drying (Manual of Methods of Analysis of Food, Beverages, Sugar and Confectionery Product, 2012). 


\section{- Food Technology}

\section{Humidity by express method}

The method is based on the drying of semi-finished products, flour on Chizhov device (Chizhov device modernized digital) according to the method (Manual of Methods of Analysis of Food, Beverages, Sugar and Confectionery Product, 2012).

\section{Lifting force}

The dough (portion is $20 \mathrm{~g}$ ) is rolled into two balls, immersed in a glass $\left(200-250 \mathrm{~cm}^{3}\right)$ with water at a temperature of $(32 \pm 2){ }^{\circ} \mathrm{C}$. The glass is put to the thermostat. The time (min) from the moment of lowering the ball to its ascent characterizes the lifting force of the semifinished product. Differences in two parallel definitions should not exceed 2 minutes.

\section{Specific volume of bread}

The volume of bread is determined using volumetric meters, which work on the principle of displacement of bread bulk filler (fine grain). The volume of the squeezed grain corresponds to the volume of the bread. Grain (sorghum, rapeseed, millet), which is sifted on metal sieves with a diameter of the upper sieve of $2.2 \mathrm{~mm}$, the lower $-1.2 \mathrm{~mm}$. The rest on the bottom sieve is used for work.

It is necessary to have two capacities, a ruler and two measuring cylinders $\left(1000 \mathrm{~cm}^{3}\right)$. The grain is filled with the excess, which is raked with the edge of the ruler into the receiving container and removed through the hole. After that, the curtains of the main capacity with grain are opened manually and put through the hole into the bucket. This grain is used for determination. Method of determination: a small amount of grain is put into the main container, bread is put on it, carefully, without passing the grain, and the rest of grain is put in excess of the capacity. Grain is raked with the edge of the ruler and put into the receiving container, and then, after opening the latch - into the measuring cylinder. The volume of grain in a cylinder $\left(\mathrm{cm}^{3}\right)$ is equal to the volume of bread. Measurements are performed twice, deviations between parallel determinations should not exceed 5\%.

The specific volume of bread is determined by dividing the volume of bread by its weight and expressed to the nearest $0.01 \mathrm{~cm}^{3} / \mathrm{g}$.

\section{Shape resistance (H/D)}

Form stability is characterized by the ratio of the height of the hearth bread $(\mathrm{H})$ to its diameter (D). $\mathrm{H}$ and $\mathrm{D}$ are determined using a special device or ruler with millimeter divisions. The greatest value of height of bread is taken. For diameter D, measure The largest and perpendicular diameters are measured and the average diameter is calculated. $\mathrm{H} / \mathrm{D}$ is calculated to the third decimal place, the result is calculated to the second decimal place.

\section{Porosity}

The porosity of bread reflects the volume of the pores in a certain volume of the crumb, expressed as a percentage to the total volume. The porosity is determined using the Zhuravlev device according to the method (Verheyen et al., 2015). 


\section{Results and discussion}

\section{Determination of the indicators of carbohydrate-amylase complex of flour}

The state of the carbohydrate-amylase complex of cereal flour was studied in comparison with varietal wheat flour, which, having its own characteristics, directly affects the course of technological processes, microbiota development and quality indicators of finished products (Drobot et al., 2014).

The results of the study of the carbohydrate-amylase complex of cereal flour compared to wheat flour are given in Table. 3.

Indicators of carbohydrate-amylase complex of flour

Table 3

\begin{tabular}{|l|c|c|c|}
\hline \multirow{2}{*}{ Indicator } & \multicolumn{2}{c|}{ Flour } \\
\cline { 2 - 4 } & $\begin{array}{c}\text { First grade } \\
\text { wheat }\end{array}$ & Oatmeal & $\begin{array}{c}\text { Green } \\
\text { buckwheat }\end{array}$ \\
\hline Sugar content, \% on the DM of flour & 0.9 & 0.7 & 1.4 \\
\hline $\begin{array}{l}\text { Sugar-forming ability, mg of maltose } \\
\text { per 10 g of flour }\end{array}$ & 180.0 & 145 & 78.4 \\
\hline $\begin{array}{l}\text { Autolytic activity, \% on the DM of } \\
\text { flour }\end{array}$ & 26 & 16.4 & 14.8 \\
\hline $\begin{array}{l}\text { Total gas formation, } \mathrm{cm}^{3} / 100 \mathrm{~g} \text { of } \\
\text { flour }\end{array}$ & 1401 & 965 & 860 \\
\hline
\end{tabular}

Buckwheat flour has more own sugars than wheat flour by $35.7 \%$, which will have a positive effect on gas formation in the dough at the beginning of fermentation. It is known that the flour's own sugars ensure the maturation of the dough only for 30-60 minutes. Further fermentation in the dough, its intensity depends on the activity of the enzymatic complex of flour and the susceptibility of starch to the action of enzymes involved in the formation of simple sugars for the fermentation process (Yurchak et al., 2009).

The activity of the enzymatic complex was determined by sugar-forming ability and autolytic activity. Thus, the sugar-forming ability of oatmeal and buckwheat flour (Table 3) is lower by 19.4 and $56.4 \%$, respectively, than in the control sample, ie, the amount and activity of enzymes is insufficient. The study of the indicator of autolytic activity (Table 3) showed that the activity of $\alpha$-amylase of oat and buckwheat flour is lower by 36.9 and $43.1 \%$, compared to wheat flour, which correlates with the sugar-forming ability. These results are explained by the grinding technology and the process of hydrothermal treatment of cereals before grinding, as a result of which some enzymes are inactivated and their activity is reduced.

It can be predicted that in the case of making products based on yeast dough only from cereal flour without the addition of wheat flour, the amount of yeast will be insufficient for further fermentation and melanoidin formation after fermentation flour own sugars, so the recipe of such products must include sugar or molasses (Lebedenko et al., 2013).

The course of gas formation was investigated in dough samples from first grade wheat flour (control sample) and from cereal flour during 5 hours of fermentation. The data of total gas formation showed (Figure 1) that the dough from oat and buckwheat flour, compared to 
wheat flour, is able to emit less carbon dioxide by $31.1 \%$ and $38.6 \%$, respectively. This indicates a lower activity of amylolytic enzymes of these types of flour, in particular $\beta$ amylase and is confirmed by low sugar-forming ability (Table 3). In addition, this is due to the technology of grinding cereals, which produces flour with low dispersion (ie, high size), which requires further research. It can be assumed that the enzymatic activity also decreases due to the technological processes of preparation of cereals for grinding (Bondarenko et al., 2019).

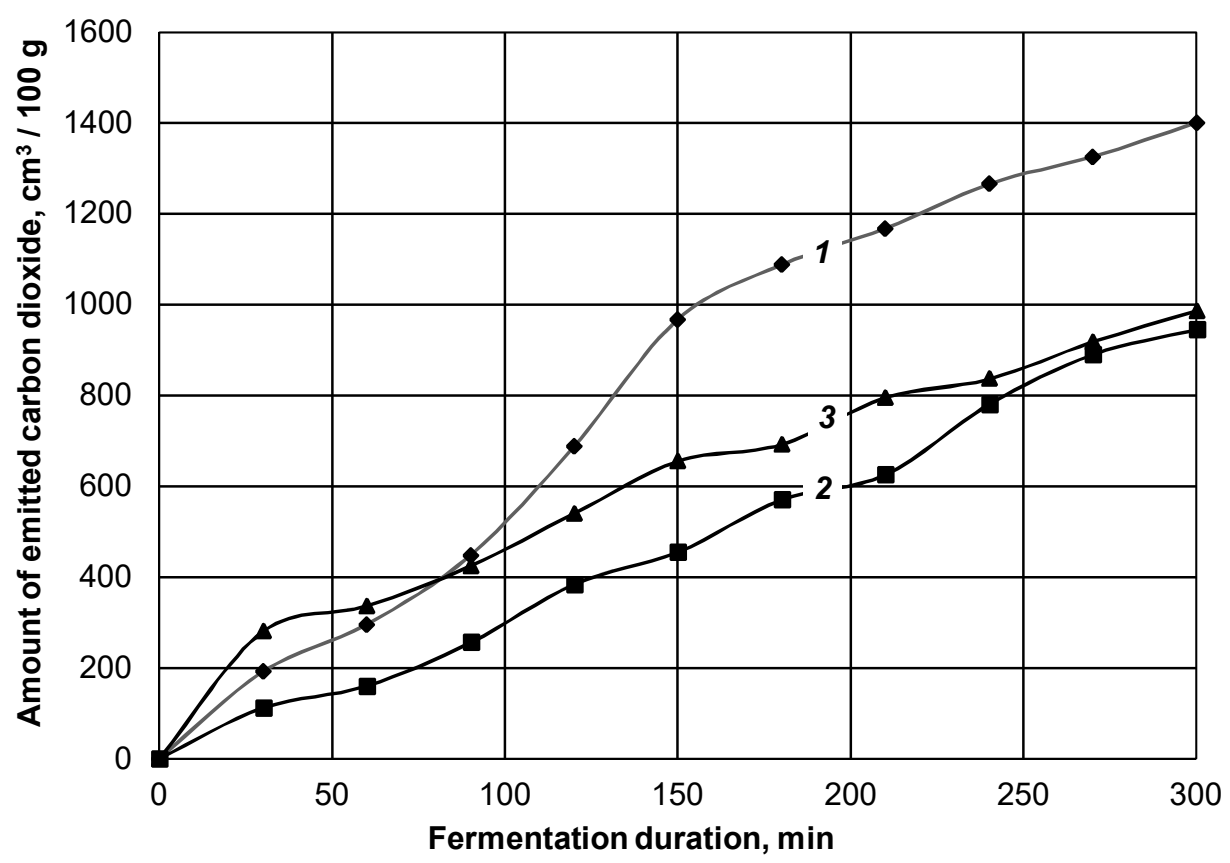

Figure 1. Total gas formation of the studied types of flour:

1 - Control sample;

2 - Green buckwheat flour;

3 -Oatmeal flour.

\section{Determination of technological parameters of wheat flour mixed with cereal flour.}

Model experiments were performed for which flour mixtures with a ratio of wheat and cereal flour of 80:20 were prepared. This ratio of flour in mixtures is due to previous studies, which found that the maximum replacement of wheat flour with cereal flour, which does not lead to a significant deterioration of the structural and mechanical properties of the dough and product quality, was $20 \%$ (Drobot et al., 2014).

In flour mixtures, as in previous samples, technological parameters were determined. The obtained results are given in Table 4 . 
Table 4

Technological indicators of mixtures of wheat flour with cereal flour

\begin{tabular}{|l|c|c|c|}
\hline \multirow{2}{*}{ Indicator } & \multirow{2}{*}{$\begin{array}{c}\text { Control sample } \\
\text { (wheat flour of } \\
\text { the first grade) }\end{array}$} & \multicolumn{2}{|c|}{$\begin{array}{c}\text { 20\% of cereal flour was added } \\
\text { instead mass of wheat }\end{array}$} \\
\cline { 3 - 4 } & 180 & 201 & Green buckwheat \\
Oatmeal \\
\hline $\begin{array}{l}\text { Sugar-forming ability, mg of } \\
\text { maltose per 10 g of flour }\end{array}$ & 1401 & 1512 & 212 \\
\hline $\begin{array}{l}\text { Total gas formation, } \\
\mathrm{cm}^{3} / 100 \mathrm{~g} \text { of flour }\end{array}$ & & 2004 \\
\hline
\end{tabular}

It was found that mixtures of wheat flour with buckwheat and oat flour have a higher sugar-forming ability by 10.4 and $15.1 \%$ (table 4 ) and the total gas formation (Fig. 2) by 7.3 and $12.7 \%$, respectively, than wheat flour. This is due to the action of $\beta$-amylase, which is contained in sufficient quantities in wheat flour, and, accordingly, in mixtures, as well as the size of starch grains and its high susceptibility to enzymes. Thus, the average values of the size of starch grains of wheat flour $-(12.4 \pm 1.9) \mu \mathrm{m}$, in oatmeal $-(7.4 \pm 0.87)$ microns, buckwheat - $(6.6 \pm 0.52)$ microns (Bonafaccia et al., 2003; Berski et al., 2011; Sakač et al., 2011). This correlates with the results of determining the technological parameters of flour, oatmeal had a higher sugar-forming ability and autolytic activity than buckwheat.

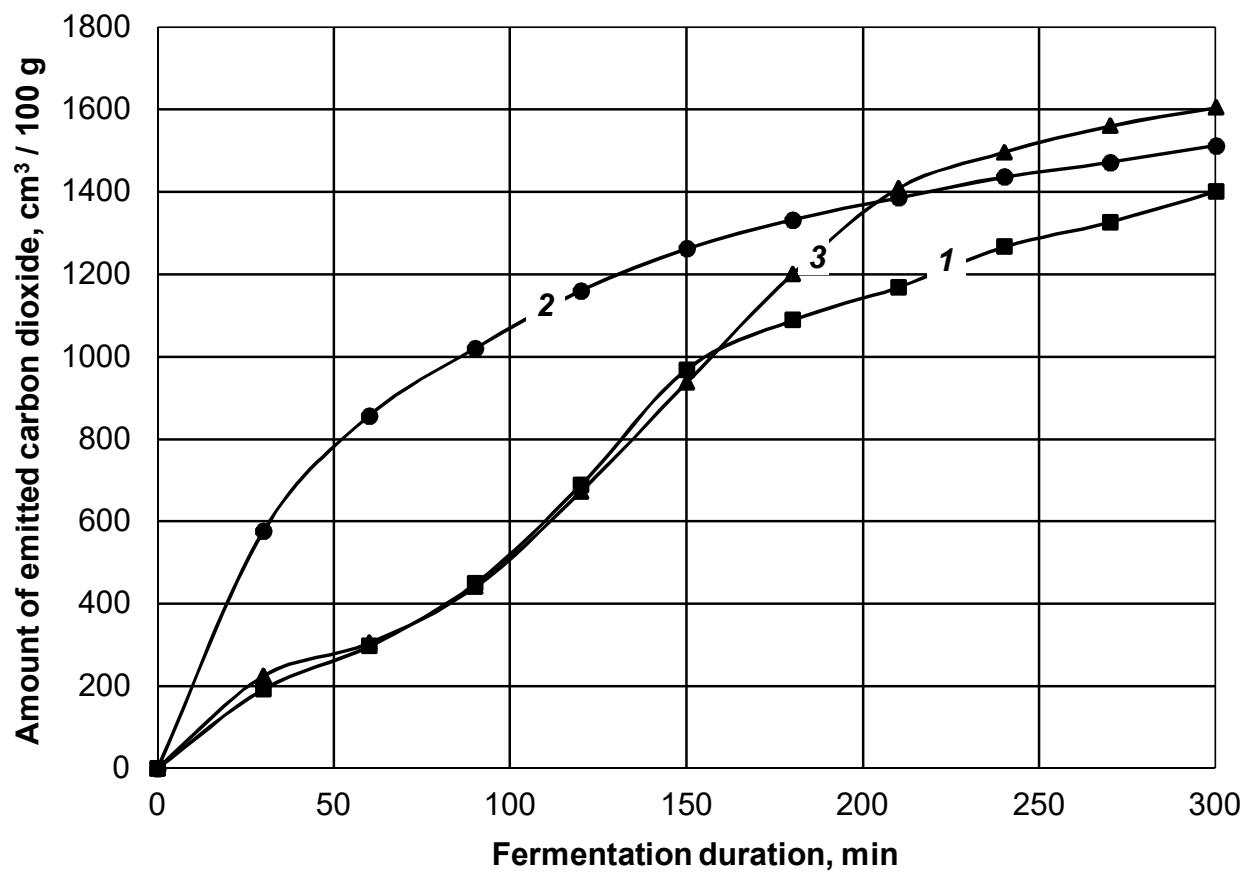

Fig. 2. Total gas formation of mixtures of wheat flour with cereal flour

1 - Control sample;

2 - Green buckwheat flour;

3 -Oatmeal flour. 


\section{Use of spontaneous fermentation leaven in the technology of wheat bread}

To determine the influence of leavens on the technological process, the dough was prepared from wheat flour of the first grade with the addition of $12 \%$ of leaven to the weight of flour (6-8\% of cereal flour was added with leaven, which replaced wheat flour). Dough with wheat leaven of spontaneous fermentation was a control sample. The results are shown in Table 5.

Table 5

Parameters of technological process and indicators of quality of wheat bread with addition of leaven of spontaneous fermentation

\begin{tabular}{|c|c|c|c|c|}
\hline \multirow{2}{*}{\multicolumn{2}{|c|}{ Indicator }} & \multirow{3}{*}{\multicolumn{3}{|c|}{\begin{tabular}{|l|}
\multicolumn{2}{|c|}{ Sample with the addition of leaven } \\
wheat (control sample)buckwheat oatmeal \\
Dough
\end{tabular}}} \\
\hline & & & & \\
\hline \multicolumn{2}{|c|}{ Dough } & & & \\
\hline \multicolumn{2}{|c|}{ Humidity of dough, $\%$} & 43.5 & 44.2 & 44.5 \\
\hline \multirow{2}{*}{$\begin{array}{l}\text { Acidity of the } \\
\text { dough, degrees }\end{array}$} & initial & 2.8 & 3.0 & 2,8 \\
\hline & final & 4.0 & 4.2 & 4,4 \\
\hline \multicolumn{2}{|c|}{ Lifting force, $\min$} & $00: 50$ & $00: 46$ & 01:01 \\
\hline \multicolumn{2}{|c|}{ Duration of aging, min } & 40 & 36 & 35 \\
\hline \multicolumn{5}{|c|}{ Bread } \\
\hline \multicolumn{2}{|c|}{ Specific volume, $\mathrm{cm}^{3} / 100 \mathrm{~g}$} & 240 & 225 & 220 \\
\hline \multicolumn{2}{|c|}{ H/D of hearth bread } & 0.48 & 0.44 & 0.46 \\
\hline \multicolumn{2}{|l|}{ Porosity, \% } & 82.0 & 80.0 & 79.0 \\
\hline \multicolumn{2}{|l|}{ Humidity, \% } & 42.8 & 43.5 & 44.0 \\
\hline \multicolumn{2}{|l|}{ Acidity, degrees } & 3.5 & 3.8 & 3.8 \\
\hline
\end{tabular}

It was found that during the fermentation period the titrated acidity increased by $1.2-$ 1.4 degrees in all samples, which is explained by the acidity of the introduced leavens. The addition of leaven had a positive effect on the lifting force. The value of the lifting force increases, approaching the control sample. This is due to the high fermentation activity of leavens (Pshenychnyuk et al.,2013; Mikhonik et al.,2018). A positive effect is observed due to the aging of the samples, as samples with the addition of buckwheat and oat leaven ripened slightly faster. This is due to the acidic medium in which the dough quickly acquires the desired rheological characteristics.

According to organoleptic parameters, the products differed slightly from each other. The crust of the bread had uniform color, from light yellow to light brown, bread with buckwheat leaven had gray tinge. The products had developed, uniform, fine and thin-walled porosity, baked and elastic crumb. The aroma and taste of the control sample is characteristic of wheat bread. The sample with the addition of buckwheat leaven had a faint aroma and taste characteristic of buckwheat flour.

The results of determining the physicochemical parameters indicated that a significant effect on the mass fraction of moisture was not observed. The higher acidity of the leaven caused an increase in the acidity of the finished products, but the values did not exceed the permissible limits. Replacing part of wheat flour with part of cereal flour in the composition of the leaven causes a deterioration in volume, shape stability and porosity, as these types of flour do not have a developed gluten skeleton (Pshenychnyuk et al., 2013; Oliinyk et al.,2017), but at the recommended dosage (Hetman et al., 2020) decreases slightly. 


\section{Conclusions}

1. Features of the chemical composition of buckwheat and oatmeal flour allow to use for the nutrient medium of leavens in order to intensify technological processes, improve the nutritional value and expand the range of bread products.

2. Studies of carbohydrate-amylase complex showed that buckwheat flour, compared to wheat flour, has more sugars, which has a positive effect on gas formation in the dough at the beginning of fermentation, but the activity of amylolytic enzymes in oatmeal and buckwheat flour is low. Thus, the sugar-forming ability of oat and buckwheat flour was lower, compared to wheat flour, by 19.4 and $56.4 \%$; autolytic activity - by 36.9 and $43.1 \%$; total gas formation - by 31.1 and $38.6 \%$, respectively. The decrease in enzymatic activity is due to differences in chemical composition and technology of preparation of cereals used to produce oatmeal and buckwheat flour.

3. Compared to the control sample, in mixtures of wheat flour with oat or buckwheat flour, the sugar-forming ability was higher by 15.1 and $10.4 \%$; gas-forming capacity - by 12.7 and $7.3 \%$, respectively. This is due to the effect of the active $\beta$-amylase of wheat flour on the smaller starch grains of cereal flour.

4. During the cultivation of spontaneous fermentation leavens from buckwheat and oatmeal flour, it was found that after the fifth renewal the quality of leavens in terms of organoleptic and physicochemical parameters is stabilized, with an acidity in the range of 16.0-18.0 degrees and LAB activity 45-60 min, and can be used in the production cycle for making bread. Provided that the necessary parameters and breeding scheme are observed, it is possible to obtain leavens with indicators which are able to ensure the course of the technological process and obtain high quality products.

5. As a result of trial laboratory baking it was found that the preparation of wheat bread using spontaneous fermentation leavens from oatmeal and green buckwheat flour in the amount of up to $12 \%$ allows to obtain products which are close to the control sample by organoleptic and physicochemical parameters.

\section{References}

Andersson am A., Armö E., Grangeon E., Fredriksson H. (2004), Molecular weight and structure units of $(1 \rightarrow 3,1 \rightarrow 4)$ - $\beta$-glucans in dough and bread made from hull-less barley milling fractions, Journal of Cereal Science, 40(3), pp. 195-204, DOI: 10.1016/j.jcs.2004.07.001

Banu Iu., Vasilean I., Aprodu I. (2010), Effect of lactic fermentation on antioxidant capacity of rye sourdough and bread, Food Science and Technology Research, 16(6), pp. 571-576, DOI: 10.3136/FSTR.16.571

Bartkiene E., Bartkevics V., Pugajeva I., Krungleviciute V., Mayrhofer S., Domig K. (2017), The contribution of P. acidilactici, L. plantarum, and L. curvatus starters and L-(+)-lactic acid to the acrylamide content and quality parameters of mixed rye - wheat bread, LWT-FOOD science and technology, 80, pp. 43-50.

Berski, W., Ptaszek, A., Ptaszek, P., Ziobro, R., Kowalski, G., Grzesik, M., \& Achremowicz, B. (2011), Pasting and rheological properties of oat starch and its derivatives. Carbohydrate Polymers, 83(2), pp. 665-671, DOI: 10.1016/j.carbpol.2010.08.036

Bonafaccia G., Marocchini M., Kreft I. (2003), Composition and technological properties of the flour and bran from common and tartary buckwheat, Food Chemistry, 80(1), pp. 9-15, DOI: 10.1016/S0308-8146(02)00228-5

Bondarenko Yu., Mykhonik L., Bilyk O., Kochubei-Lytvynenko O., Andronovich G., Hetman, I. (2019), Study of the influence of buckwheat flour and flax seeds on consumption properties of 
long-stored bakery products, EUREKA: Life Sciences, 4, pp. 9-18, DOI: 10.21303/25045695.2019.00973

Chelyabiyeva V., Sosedova K. (2018). Vykorystannya zakvasok spontannogo brodinnya ta boroshna bobovyh kultur u vyrobnycztvi hliba [The use of spontaneous fermentation and legume flour in the production of bread], Tehnichni nauky ta tehnologiyi [Technical sciences and technologies], 3, pp. 251-257.

Coda, R., Di Cagno, R., Gobbetti, M., \& Giuseppe, R.C. (2014), Sourdough lactic acid bacteria: Exploration of non-wheat cereal-based fermentation, Food Microbiology, 2, pp. 51-58. , DOI: 10.1016/j.fm.2013.06.018

Coelho, M.S., \& de Salas-Mellado M. (2015), Effects of substituting chia (Salvia hispanica L.) flour or seeds for wheat flour on the quality of the bread, LWT-Food Science and Technology, 60(2), pp. 729-736, DOI: 10.1016/j.lwt.2014.10.033

Demirkesen Mert I., H. Campanella O., Sumnu G., Sahin S. (2014), Gluten - free sourdough bread prepared with chestnut and rice flour, Foodbalt, 26(1), pp. 239-242.

De Vuyst, L., \& Neysens, P. (2005), The sourdough microflora: biodiversity andmetabolic interactions, Trends in Food Science \& Technology, 16(4), pp. 43-56, DOI: 10.1016/j.tifs.2004.02.012

Drobot, V., Semenova, A., Smirnova, J., \& Mykhonik, L. (2014), Effect of buckwheat processing products on dough and bread quality made from whole-wheat flour, International Journal of Food Studies, 3(1), pp. 1-12, DOI: 10.7455/ijfs/3.1.2014.a1

Dziadeka K., Kopeća A., Pastucha E., Piątkowska E., Leszczyńska T., Pisulewska E., Witkowicz R., Francik, R. (2016), Basic chemical composition and bioactive compounds content in selected cultivars of buckwheat whole seeds, dehulled seeds and hulls, Journal of Cereal Science, 69, pp. 1-8, DOI: 10.1016/j.jcs.2016.02.004

Flander L., Salmenkallio-Marttila M., Suortti T., Autio K. (2007), Optimization of ingredients and baking process for improved wholemeal oat bread quality, Food Science and Technology, 40(5), pp. 860-870, DOI: 10.1016/j.lwt.2006.05.004

Hetman I.A., Mykhonik L.A., Naumenko O.V., Kukharenko I.O. (2020), Vykorystannia zakvasok spontannoho brodinnia $\mathrm{z}$ boroshna krupianykh kultur $\mathrm{v}$ tekhnolohii pshenychnoho khliba [The use of spontaneous fermentation of cereal flour in the technology of wheat bread], Yakist $\mathrm{i}$ bezpechnist kharchovoi produktsii i syrovyny - problemy sohodennia: materialy Mizhnarodnoi konferentsii, 25 veresnia, $2020 \mathrm{r}$. [Quality and safety of food products and raw materials - the problems of today: materials of the International Conference, September 25, 2020], Lvivskyi torhovo-ekonomichnyi universytet [Lviv University of Trade and Economics], Lviv, pp. 78-80.

Harth H., Kerrebroeck S. V., De Vuyst L. (2016), Community dynamics and metabolite target analysis of spontaneous, backslopped barley sourdough fermentations under laboratory and bakery conditions, International Journal of Food Microbiology, 228(2), pp. 22-32.

Ivanov V., Shevchenko O., Marynin A., Stabnikov V., Gubenia O., Stabnikova O., Shevchenko A., Gavva O., Saliuk A. (2021), Trends and expected benefits of the breaking edge food technologies in 2021-2030, Ukrainian Food Journal, 10(1), pp. 7-36, DOI 10.24263/2304-974X-2021-10-13.

Kaprelyants L., Yegorova A., Trufkati L., Pozhitkova, L. (2019), Functional foods: prospects in Ukraine, Food science and technology, 13(2), pp. 15-23, DOI: 10.15673/fst.v13i2.1382

Korniyenko I. M. (2019), Physical-chemical and microbiological research of yeast-free sourdough for bakery products of functional purpose, Problems of ecological biotechnology, 2, pp. 1-15, DOI: 10.18372/2306-6407.2.14756

Lebedenko T., Kozhevnikova V., Kotuzaki O., Novichkova T. (2019), Determining the efficiency of spontaneous sourdough for stabilizing the quality of bread products in bakeries and catering enterprises, Eastern-European Journal of Enterprise Technologies, 4(11), pp. 22-35, DOI: 10.15587/1729-4061.2019.174289 
Manual of Methods of Analysis of Food, Beverages, Sugar and Confectionery Product. 2012; Lab. Manual 4. Available at: https://old.fssai.gov.in/Portals/0/Pdf/15Manuals/BEVERAGES, \%20SUGARS\%20\&\%20CONFECTINERY.pdf (accessed on 31 October 2021)

Mikhonik L.A., Getman I.A., Bela N.I., Bogdan G.S. (2018), Pokaznyky yakosti zakvasok spontannoho brodinnia $\mathrm{z}$ boroshna krupianykh kultur $\mathrm{V}$ protsesi nyzkotemperaturnoho konservuvannia [Quality indicators of the spontaneous fermentation starters of cereals flour during the lower-temperature conservation process], Prodovolchi resursy [Food Resources], 11(13), pp. 116-122, DOI: 10.31073/foodresources2018-11-13

Moroni Alice V., Arendt Elke K., Dal Bello F. (2011), Biodiversity of lactic acid bacteria and yeasts in spontaneously - fermented buckwheat and teff sourdoughs, Food Microbiology, 28(3), pp. 497502.

Moroni Alice V., Zannini E., Arendt Elke K., Sensidoni G. (2012), Exploitation of buckwheat sourdough for the production of wheat bread, European Food Researchand Technology, 10, pp. 23-27.

Munteanu G.-M., Voicu G., Ferdeș M., Ștefan E.-M., Constantin G.-A., Tudor P. (2019), Dynamics of fermentation process of bread dough prepared with different types of yeast, Scientific Study \& Research, 20(4), pp. 575-584.

Oliinyk S.H., Stepankova H.V., Samokhvalova O.V. ta in. (2017), Tekhnolohiia khliba pshenychnoho z produktamy pererobky zarodkiv vivsa ta kukurudzy [Technology of wheat bread with products of oat and corn germ processing], Kharkivskyi derzhavnyi universytet kharchuvannia ta torhivli [Kharkiv State University of Food and Trade], Kharkiv, 123 p.

Pshenychnyuk G.F., Chaban A.B. (2013), Zbagachennya himichnogo skladu zhytno-pshenychnyh vyrobiv na osnovi konservovanyh zakvasok spontannogo brodinnya [Enrichment of chemical composition of rye-wheat products on the basis of canned leavens of spontaneous fermentation], Harchova nauka i tehnologiya [Food science and technology], 1(22), pp. 12-14.

Rasane, P., Jha, A., Sabikhi, L., Kumar, A., \& Unnikrishnan, V.S. (2015), Nutritional advantages of oats and opportunities for its processing as value added foods - a review, Journal of Food Science and Technology, 52(2), pp. 662-675, DOI: 10.1007/s13197-013-1072-1

Rushaj O. S., Gregirchak N. M. (2012), Doslidzhennya mikrobiologichnyh pokaznykiv zakvasky ta hliba iz proroshhenogo zerna pshenyci, Ukrainian food journal, 2, pp. 39-42.

Sakač, M., Torbica, A., Sedej, I., \& Hadnađev, M. (2011), Influence of breadmaking on antioxidant capacity of gluten free breads based on rice and buckwheat flours, Food Research International, 44(9), pp. 2806-2813, DOI: 10.1016/j.foodres.2011.06.026

Sharma, R., Garg, P., Kumar, P., Bhatia, S.K., \& Kulshrestha, S. (2020), Microbial fermentation and its role in quality improvement of fermented foods, Fermentation, 6(4), p. 106, DOI: 10.3390/fermentation6040106

Sylchuk, T., Bilyk, O., Kovbasa, V., \& Zuiko, V. (2017), Investigation of the effect of multicomponent acidulants on the preservation of freshness and aroma of rye-wheat bread, Eastern-European Journal of Enterprise Technologies, 11(89), pp. 4-9, DOI: 10.15587/1729-4061.2017.110154

Verheyen C., Albrecht A., Elgeti D., Jekle M., Becker T. (2015), Impact of gas formation kinetics on dough development and bread quality, Food Research International, 76(3), pp. 860-866, DOI: 10.1016/j.foodres.2015.08.013

Yurchak V., Rak V., Daxno B., Cerkovna S. (2009), Povertayemosya do pryzabutoyi texnologiyi vypikannya xliba na xmelevyx zakvaskax [We return to the forgotten technology of baking bread on hop leavens], Xlibopekarska i kondyterska promyslovist Ukrayiny [Bakery and confectionery industry of Ukraine], 3(52), pp. 39-41.

Zannini E., Garofalo C., Aquilanti L., Santarelli S., Silvestri G., Clementi F. (2009), Microbiological and technological characterization of sourdoughs destined for bread-making with barley flour, Food Microbiology, 26(7), pp. 744-753. 